\title{
FIRST NATIONS ON VIEW: \\ Canadian Museums and Hybrid Representations of Culture
}

by Susan Ashley

M useums are important public sites for the representation and authentication of history and heritage in Canadian society. The study of history and ethnographic museums allows important insights into issues of race, ethnicity and identity, and especially how the colonial legacy has shaped how Canadians see themselves. Museums are a supreme expression of imperialist Europe - publicly funded institutions devoted to colonial sensibilities. This includes vast halls set up to display the "booty" of war and conquest as well as the mounds of material evidence produced by scientific research and collecting. Museums of the 19th century were concerned with objects (and objectifying) and possessed a foundational purpose to define what was cultured or civilized (and what was not). Early exhibits emphasized purity of race, the progression of history and the sense that the "white" European race was the pinnacle of evolution. Museums defined, and continue to define and present who we are as nations or communities or cultures, and inevitably separate the we from everyone else out there (Bennett, 1995; Hooper-Greenhill, 1999). By using exhibition as its form of communication, museums set up frozen instances in time and fixed them, unchangeable, as expert truth; there was no opportunity then to contest or even engage in dialogue. Objects displayed, in public, for audiences to gawk at or exclaim over. This very act of exhibition was spectacular in the Debordian sense: a representation, divorced from reality, is presented to and consumed by an undifferentiated audience.

Recently there has been great hand-wringing over the new, post-colonial role for the museum and how it functions as a place of representation, socialization and commodification. (Hein, 2000; Hallam \& Street, 2000; Kary \& Levine, 1991). Much has been made 
of how to ensure participation and inclusion with the aim of creating unbiased cultural representations and developing new, non-white, audiences (Sandell, 2002). But at their core museums retain two basic competencies left over from colonial times - they collect and they exhibit. Both activities have been called Western preoccupations not shared by all cultures (Clifford, 1997). How have communities with non-Western ethnicity, especially North American First Nations peoples, responded to the call for them to participate in the museum realm? As the object of the colonial museum's gaze, how has their relationship to museums changed in post-colonial times? What happens when the Western notion of collecting and exhibiting is rejected?

I believe the answer lies in exploring the concept of hybridity. In this paper, I will consider hybridity and museums in two ways. Firstly, how First Nations cultures have changed and become hybrid themselves and, secondly, how First Nations peoples are using, challenging and twisting the function and processes of this white man's institution, the museum, and creating hybrid forms. I consider the ways in which different forms of the modern museum created by First Nations groups express different concepts of hybrid identities, whether through forms of mimicry, fusion, juxtaposition, subversion, or Bhabha's "third space" where identity is constructed through the negotiation and holding-together of difference (see Crossley, 2005).

In the 19th century, scientific natural history and ethnographic collections formed the basis of early Canadian museums. These early institutions offered an academic, disciplinary and Anglo-centred view of history and the world (Gillam, 2001). Until the 1970s the treatment of First Nations in Canadian museums, and non-Anglo cultures in general, was either anthropological or non-existent. First Nations narratives were often isolated either in detached spaces within natural history museums, or in separate anthropological museums, effectively separating native collections and stories from mainstream narratives (Ruddell, 2004). But it was in 
the anthropological museum, specifically dealing with First Nations issues, that museum practice in Canada began to change. In western Canada, museums like the Glenbow began to include some native input into programming, staffing and exhibits as a response to native activism and a heightened public awareness of First Nations' social issues (Haas, 1996). As well, cultural pride and activism resulted in the creation, by First Nations groups themselves, of museums specifically devoted to expressing indigenous perspectives on culture and heritage (Phillips, 2003). By the 1990's, ownership, protection and repatriation of indigenous cultural property became an international issue, and some significant collaborations were undertaken in public museums both in Canada and other Western countries (Haas, 1996). The topic of First Nations in Canadian museums changed from a scientific, anthropological orientation to identity work. Museum representations moved from native peoples as objects of study, to public declarations by First Nations themselves about who they were and how they contributed to the Canadian collage.

Inherent in this process is the problem of trying to define these diverse peoples who have been altered through colonial encounters. Native attempts to present traditional cultures, disrupted by European contact, have involved picking up pieces, then creating a new, hybrid voice, an amalgam of white culture, tribal culture and the traditions of other First Nations cultures from across North America (Crossley, 2005). The result is the creation of the Pan-Indian who is a hybrid of many different identities. Two obvious examples that demonstrate this hybridity are pow wows and feather headdresses —strong modern-day First Nations identifiers, but not something that all historic native cultures used.

This new voice, the hybrid voice, has made use of the museum in diverse ways. At first glance the use of this Old World medium with its embodied colonialism seems inappropriate for use by First Nations groups. The core objectives of collecting and exhibiting seem at odds with a native worldview. Are the acts of accumulating and publicly displaying physical things part of human nature 
or Western culture? By using the museum form are First Nations mimicking Europeans? Or is their use of a museum not only a twist on the old function of museums, but a new medium of public identity presentation for these hybrid entities?

The way that First Nations work through problems with the museum institution is reflective of hybrid ways of seeing the world and being seen in the world. I am using two variables here: seeing and showing. Seeing involves how an entity views the world whereas showing constitutes how that entity is shown or exhibited to the world. I also explore how the medium of museums is used differently depending on the audience. Are they reflecting identity internally, to themselves, or are they showing themselves to others, in public, to the outside world? The inward projections tend to be about tribal solidarity and education. The outward projection is meant to declare resistance, contestation and a public decree: "We • have • arrived."

Museum exhibitions today on First Nations themes are either generated by natives themselves or must involve a great deal of collaboration or consultation with First Nations groups (Phillips, 2003). And while colonial-era depictions are now recognizably paternalistic, orientalized and objectifying, classic colonial tropes still appear in museum exhibition. A visit to the basement of the Royal Ontario Museum will demonstrate that. The "traditional" Indian is overwhelmingly rendered in these depictions in a safe, ethnographic way for consumption by westerners - no signs of controversy or resistance here. Parts of First Nation cultures are also cannibalized or appropriated as the useful elements are incorporated to tell the mainstream exhibition narratives of European settlement or trade.

I will focus on those museums where First Nations peoples themselves are the agents, the drivers, the articulators. In particular I have concentrated on examples of: 1) Alternative constructions of identity using Old World museum techniques, 2) Multi-vocal depictions of identity where both European and First Nations bodies occupy the same space, and 3) New identity constructed through negotiation of difference using the museum space in entirely new 
ways; in short, seeing and showing in a hybrid way. There are four examples of museum work which illustrate hybrid techniques. Firstly is the Woodland Cultural Centre in Brantford. This facility is an excellent example of a native-driven museum project. Founded in the 1970's, the goal of the Centre is to preserve and present the heritage of Iroquois First Nations. Interestingly, the perspective is definitely Western museological in that the museum's mandate is expressed in scholarly terms emphasizing research, collections, textualization, and discourse. Its curators and staff, while native, have classic museum training. The Centre was established as a public declaration of the presence of the Iroquois in a white world and they use white man's language and visual forms to express this. The text might reflect native worldview, but by the very fact that Western exhibit techniques of text panels, dioramas, photos-as-graphics and linear time narrative are used, the message conveyed is very Eurocentric. Though, the white cultural form called the museum with its collections and exhibitions sits comfortably here the identities they assert are hybrid ones. Is the Woodland Cultural Centre an example of native resistance or of mimicry? Is this the case of a colonized people absorbing the culture of the colonizers? This is a key question in an ongoing postcolonial debate: by choosing to use the organizational structure and the methods of the dominant culture, have the oppressed been co-opted or are they legitimately functioning as new entities in modernity?

A far more subversive result occurs at the First Peoples Hall at the Canadian Museum of Civilization in Ottawa. Here First Nations and non-First Nations collaborated on a museum representation that took 11 years to develop. Ruth Phillips (2003) calls this kind of exhibit a "multi-vocal" one in that it reflects discordant presentations within one exhibit. A true case here of Bakhtin's hybridity - two bodies occupy the same space. Or as Bakhtin has written, "two social languages within the limits of a single utterance" (Papastergiadis 183). First Nations stories and objects are presented from two points 
of view here, native and white, in a parallel construction that can be viewed as vital, affective and exciting but can only be described as chaotic to a standard white observer. An example is the juxtaposition in the exhibit of traditional ways of life interpreted using standard ethnographic treatment side by side with OKA clan mothers' stories of women's politics. Important here is the carrying forward of the untranslatable bits rather than their "consumption" by the dominant culture, which in Bhabha's sense are those parts that make sense to the originator and cannot be smothered or appropriated by the colonizer (Crossley, 2005). There is no "translation" attempted; whites are not expected to be able to access this information. As a result, some "typical" museum-goers have been upset by the exhibition, objecting to the inaccessibility of the hybrid presentation.

Inaccessibility is the knock on another museum in a national capital, the National Museum of the American Indian, just opened in Washington, D.C. In a clear declaration of empowerment, this museum is a huge, sprawling piece of architecture by Canadian native architect Douglas Cardinal. It offers an alternative construction of First Nations identity using an exhibitionary mode that picks and chooses bits of traditional museological techniques. The goal of representation was unique: to accommodate the myriad of native tribes in the U.S., many people, expert and lay, created the expressions, media and forms used (Rickard, 2004).

The mainstream press reaction to the new museum has been hostile. It has been condemned as amateur, confusing, uneven, and chaotic. The extreme of the venom is reflected in the words of one critic: "Almost all the exhibits have been designed by Native peoples themselves, with a minimum of curatorial oversight, and it shows." (Adams, 2004). White audiences and critics bring their expectations of how a museum should behave and are critical if this is not met. They also still bring their expectations of how other cultures should behave in a museum, some expressing that First Nations should depict prehistoric cultures in their museums, not modern cultures. First Nations acting modern is interpreted as "inauthentic" or in this 
case, needing a strong authoritative hand (Adams, 2004). Despite these "white" critiques, the whole experience, the visual and experiential, has succeeded in conveying an overwhelming Indian-ness. The museum has definitely established the idea that these cultures are different from the dominant culture.

A fourth example takes the museum even farther away from its traditional form and into an evolutionary hybrid. Here both of the Western functions of museums - collecting and exhibiting - are put aside. Instead, a new identity is constructed through negotiation of difference. First Nations see the world and are seen in the world in a distinctive way. In a now-famous article James Clifford speaks of museums as "contact zones," places where museums are not public presentations of artifacts but act as a forum for community interaction (192). Clifford used as his example an encounter at a West Coast museum between curators and Tlingit First Nations elders. White museum curators expected that the native peoples would collaborate with them in identifying valuable objects of Tlingit origin in their collection. Instead, the elders were not particularly interested in the artifacts themselves, but in the ritual and songs that were associated with them. The performance and stories about ancestors were what mattered. Rather than representations of history or even identity, the museum in these terms becomes a forum for social relations, a community centre for performance, storytelling, tribal politics and education. The Tlingit, the Kwagulth and other West Coast tribes are making the medium of the museum do unexpected things. A new vocabulary emerges out of this hybrid situation, a third space of dialogue where all elements are transformed, both the native and European voices, through negotiation of difference.

\section{Conclusion: problem areas}

In addressing how they should deal with this Old World institution, First Nations peoples have helped to highlight some of the problems inherent in the museum institution, and First Nations identity work in general. First, I am troubled by the silences in much of this museum 
work. We often see celebratory, positive images conveyed but where are the histories of intertribal genocides, or violence against women? Perhaps the myth-building continues within First Nations communities themselves Even museums as contact zones must include all voices in their negotiation and articulation of identity. Second, I question what has happened to the mongrel in native representations of Indian-ness? Status Indians, while hybrid in essence, are getting exhibition time. However, historic hybrids like the Métis or modern mixes between natives and non-natives seem to be absent. Ironically, one must ask if there is an "othering" going on here between those who officially qualify as First Nations and those who do not?

Third, and related to the first two, is there a place within the museum institution for the performance of opposition or resistance and subversion? Certainly not within the museum walls, where the instant there is a representation or a contact, there is an admission of collusion or accommodation or negotiation. By using this institutional space do we neuter its capacity for subversion, and commodify resistance? It raises the question of the utility of the museum forum. Perhaps resistance will happen where it always does - just outside on the museum steps. Note that the museum is often a site of resistance not through their exhibitions inside, but as locations for protest activity. The Lubicon brought their land claims protest to the Glenbow's Spirit Sings exhibit not because of the content of the exhibit but because they needed a public forum and the museum was perceived as an institution of mainstream culture.

In conclusion, it is easy to change a small museum, or build a single-ethnic institution, but how to move towards the "contact zone" in the mega-museum like the Royal Ontario Museum? Focused exhibits and community participation are the favoured techniques at this point. However, relinquishing authority in the construction of meaning continues to be an issue. But as the First Nations examples suggest, the museum will become a far more democratic institution when it is a tool of its communities and fairly represents the kind of heritage its citizens wish to be discussed, displayed, commemorated and archived. 


\section{Works Cited}

Adams, Jim. "National Museum of the American Indian reviews: Ceremonies were nice but critics pan content." Indian Country Today. 16 Mar. 2005 <http://www.indiancountry.com/content.cfm?id=1095411355>.

Bennett, Tony. The Birth of the Museum: History, Theory, Politics. New York: Routledge, 1995.

Clifford, James. "Museums as Contact Zones." Routes: Travel and Translation in the Late Twentieth Century. Cambridge: Harvard UP, 1997.

Crossley, Nick. Key concepts in critical social theory. London: SAGE, 2005.

Gillam, Robyn. Hall of Mirrors: Museums and the Canadian Public. Banff: The Banff Centre P, 2001.

Haas, Jonathan. "Power, Objects and a Voice for Anthropology." Current Anthropology 31 Supplement (1996): S1-S22.

Hallam, Elizabeth, and \& Brian Street, eds. Cultural Encounters: Representing 'Otherness.' New York: Routledge, 2000.

Harrison, Julia. "Museums as agencies of neocolonialism in a postmodern world." Studies in Cultures, Organizations and Societies 3 (1997): 41-65.

Hein, Hilde S. The Museum in Transition: A Philosophical Perspective. Washington, DC: Smithsonian Institution P, 2000.

Hooper-Greenhill, Eilean, ed. Museums and the Shaping of Knowledge. New York: Routledge, 1999.

Karp, Ivan and Stephen Lavine, eds. Exhibiting cultures: the poetics and politics of museum display. Washington, DC: Smithsonian Institution P, 1991.

Mabardi, S. "Encounters of a Heterogeneous Kind: Hybridity in Cultural Theory." Critical Studies 13.1 (June 2000): 1-20.

Papastergiadis, Nikos. The Turbulence of Migration: Globalization, Deterritorialization and Hybridity. Cambridge, UK: Polity Press, 2000.

Peers, Laura, and Alison Brown, eds. Museums and Source Communities. New York: Routledge. 2003.

Phillips, Ruth. "Introduction: Community Collaboration in Exhibits." Museums and Source Communities. Eds. LauraPeers and Alison Brown. New York: Routledge, 2003: 155-170. 
FIRST NATIONS ON VIEW O SUSan AshIey

Rickard, Jolene. "Assessing Aboriginal Representation at the National Museum of the American Indian." Unpublishedpaper presented at (Re)Visualizing National History: Museology and National Identities in the New MillenniumConference. U of Toronto. 4 Mar. 2004.

Ruddel, Thiery. "Negotiating National Narratives in CanadianMuseums."

Unpublished paper presented at(Re)Visualizing National History:

Museology and National Identities in the New Millennium Conference. U ofToronto. 5 Mar. 2004.

Sandell, R., ed. Museums, Society, Inequality. New York: Routledge, 2002.

Simpson, Moira G. Making Representations: Museums in the post-colonial era. New York: Routledge, 1996. 